\title{
IS PROPHETHOOD SUPERFLUOUS? Conflicting Outlook on the Necessity of Prophethood between Badiuzzaman Said Nursi and Some Muslim Philosophers $^{1}$
}

\section{Fauzan Saleh}

State College for Islamic Studies (STAIN) Kediri, Indonesia email:fsaleh04@yahoo.com

\section{Abstract}

As early as tenth century, Abü Bakr al-Rǟō (d. 925), a notable figure in Islamic philosophy, claimed that prophethood is entirely superfluous, since God imparted the gift of reason to bumankind, and reason is enough to guide them. Al-Rärîs skeptical view sounds provocative, and thus worthy of further study. However, some other philosophers, like al-Faräbì, Ibn Sinā and Ibn Maskawaih, acknowledge the necessity of prophethood for the guidance of human life. Their idea, though formulated in different reasoning from the one held by Muslim theologians, indicates their acceptance of the authority of divine revelation. On the other hand, Said Nursi, one of the greatest Muslim reformers in the modern time, maintains that since "divine power does not leave the ant without leader, or bees without a queen, it surely would not leave mankind without prophet or code of law." After all, the order of the world necessitates the existence of the prophets to preserve its solidity. This article will scrutinize more critically Nursi's idea on the necessity of divine revelation that would enlighten human path to truth, to be compared with some ideas held by Muslim philosophers in discussing the relationship between reason and revelation, and its corollaries.

[Filsuf besar dari abad ke-10, Abù Bakr al-Rā̄ị (w. 925), menyatakan

1 The first version of this article was presented at the 10th International Baediuzzaman Symposium "The Role and Place of Prophethood in Human's Journey to the Truth: the Perspective of Risale-i Nur”, Istanbul 21-25 September 2013 
babwa diutusnya seorang nabi sebenarnya tidak perlu lagi, karena Tuban telah menganugerabkan akalpada manusia yang akan mampu membimbing mereka. Pandangan skeptis dari al-Rą̈ī ini terdengar provokatif dan perlu dieksplorasi lebih lanjut. Namun, beberapa filsuf seperti al-Farabi, Ibnu Sina, dan Ibn Maskawaih mengakui perlunya nabi untuk membimbing manusia. Pandangan para filsuf ini, meski dengan nalaryang berbeda dengan para abli teologi, mengindikasikan penerimaan terhadap otoritas wahyu ketuhanan. Di sisi lain, Said Nursi, seorang pemikir-reformis modern, menyatakan bahwa karena "kuasa Tuban tidak pernah membiarkan sekawanan semut tanpa pemimpin, atau sekelompok lebah tampa ratunya, maka pastilah manusia juga tidak akan dibiarkan tanpa seorang nabi atan syariat." Lebih dari itu, tata dunia juga memerlukan kehadiran seorang nabi untuk menjaga soliditasnya. Tulisan ini akan melihat secara lebih dalam dan kritis mengenai pemikiran Said Nursi tentang pentingnya wahyu ketubanan untuk menerangi langkah manusia menemukan kebenaran; kemudian dibandingkan dengan pandangan filsufffilsuf muslim lainnya dalam membincang keterkaitan nalar dan wabyu dengan segala konsekuensinya.]

Keywords: prophethood, Said Nursi, miraculousness of the Quran, al-Rāzì, divine revelation

\section{A. Introduction}

Allah has sent some messengers to humankind as a manifestation of His blessing and favor. These messengers of God brought forth glad tidings to guide humankind so that they might be aware of the true path of the good life and achieve their ultimate well-being. Nevertheless, not all human beings will voluntarily follow the guidance brought by those messengers of God. They maintain that human beings have been enlightened by their capacity of reasoning, and that would be sufficient for them as a means to achieve the truth and happiness. Accordingly, they assumed that the presence of the prophets as the messengers of God with divine revelation they claimed to convey would be superfluous. To say the truth, however, not every single person has a well-trained intellectual aptitude. Many would be very much dependent on other persons' judgment and decision. They would be prone to be prey of treachery by those who claim to be commanding over other people. In reality, such a tendency has been very common to take place in a nation that falls under the tyrant, non-democratic leaders. 
In fact, the refutation against the presence of the prophets has happened since the very beginning of Islam. The Quran has clearly recorded the standpoints and conducts of people rejecting the divine messages conveyed by the Prophet. They did it entirely either out of ignorance or of obstinacy and malice. The Quran, 25:7-10, for instance, reveals such a behavior performed by the Arabs who belittled Muhammad's character as being an improper person to convey divine messages, just because he could not have, as they claimed, showed any grandeur or performed astonishing action. The verse reads:

And they say: "what sort of a messenger is this who eats foods, and walks through the streets? Why has not an angel been sent down to him to give admonition with him? Or (why) has not a treasure been bestowed on him, or why has he (not) a garden for enjoyment? The wicked say: "ye follow none other than a man bewildered."

Al-Marāghī, in his interpretation on the above verses recounts a narration attributed to Ibn Abbas, explaining that one day some Arab leaders made a gathering in which Muhammad was invited to join. Upon his appearance, one of the Arab leaders addressed him, saying: "O Muhammad! As the envoys of the Arab dignitaries, we are here to make an apology to you. But should you bring forth this message just for the more prosperity to gain, we would compassionately stockpile for you our wealth. If you do that in order to obtain more glory, we are ready to make you our chieftain, and if you do that because you want to gain sovereignty over our people, we are willing to make you a king." In response to such an appeal, the Prophet was reported to have said: "But I have nothing to do with all of what you said. I did not bring forth this message to you for the sake of wealth, tribute, or even sovereignty over all of you. Rather, God has sent me as a messenger to you, as He brought down to me a holy scripture. He enjoined me to be a bearer of glad tidings and as a warner to you. Hence, I have delivered the divine message to you as well as I have advised you. Should you accept what I have brought forth to you that would be your own fate, both for your worldly life and for your life in the Hereafter. But, if you decline, I will be unwearied until God impartially determines His judgment over all of us." The Arabs replied: "O Muhammad, if you do not accept anything of what we have offered you, then ask your Lord to send an angel with

2 The translation of the Quranic verses referred to in this article is based on Abdullah Yusuf Ali, The Meaning of the Holy Qur'an (Beltsville: Amana Publications, 1997). Al-jāmíah, Vol. 53, No. 1, 2015 M/1436 H 


\section{Fauzan Saleh}

you to authenticate everything you said. Likewise, ask Him to endow you with gardens and palaces made of gold and silver, so that you may not unavoidably do as what we see you doing. You go through the market streets to comply with your basic needs, so that we hardly recognize your dignity and your reputation as the messenger of your Lord that you claimed." Again, in response to such a request, the Prophet said: "I would not do that, I am not the one who would ask that to his Lord; and I am not sent to you for that purpose. Instead, Allah has sent me as a bearer of glad tiding and as a warner..."3

It is not astonishing then, when as early as the tenth century, Abu Bakr al-Rāzì (d. 925), a notable figure in Islamic philosophy, claimed that prophethood is pointless. He argues: "what need does humankind have for prophethood or divine revelation, since God initially imparted the gift of reason to them from the essence of His divinity?" According to his point of view, "reason is enough to enlighten or guide humankind, and thus prophethood is entirely superfluous." More decisively, he maintained that "the competing claims of diverse revelation have been the cause of endless bloodshed and warfare between the nations favored with divine revelation and those who were not"4 Al-Rāzì's skeptical view sounds provocative, and thus worthy of further study. However, some other philosophers, like al-Farabi, Ibn Sīnā and al-Kindi, acknowledge the necessity of prophethood for the guidance of human life. Their idea, though formulated in different reasoning from the one held by Muslim theologians, indicates their acceptance of the authority of divine revelation. On the other hand, Said Nursi, as one of the greatest Muslim reformers in the modern time, maintains that since "divine power does not leave the ant without leader, or bees without a queen, it surely would not leave mankind without prophet or code of law." After all, the order of the world necessitates the existence of the prophets to preserve its solidity. ${ }^{5}$ This article will scrutinize more critically Nursi's idea on the necessity of divine revelation that would enlighten human path to truth, to be compared with some ideas held by some Muslim theologians and philosophers in discussing the necessity of prophethood for the

${ }^{3}$ Aḥmad Musțāfā al-Marāghī, Tafsìr al-Marāghì, vol. 27 (Beirut: Dār Ihyā̄' al-Turath al-Arabi, 1985), pp. 154-5.

${ }^{4}$ Majid Fakhry, A Short Introduction to Islamic Philosophy, Theology and Mysticism (Oxford: Oneworld, 1997), p. 734.

${ }^{5}$ Badiuzzaman Said Nursi, The Words, trans. by Sukran Vahide (Istanbul: Sozler Publication, 2008), p. 734. 
betterment of humanity.

\section{B. Some Skeptical Views on the Necessity of Prophethood}

The explosion of scientific achievement and technological capacity in modern times has brought many improvements to human race. Technological advances have greatly increased human ability to control and direct the forces of nature, but they have also turned out to have an unexpected and possibly uncontrollable impact on environment and in due course endangered human life. ${ }^{6}$ Thus, the advance of science and technology made humans more independent and autonomous. They claimed that the world has been thoroughly explored, and there should be no more secret unrevealed, thanks to their intellectual aptitude. Human beings have experienced great changes from the time of mythology to the information and digital era. Modern people even declare that "the more we believe in science, the less we are likely to be deceived by superstitions." Such a claim indicates that religious belief, which is seen as closer to superstition, has no more place in modern time. Revelation and religious dogmas are left behind, to be replaced by science and technology, which are ultimately based on reason. In the modern world overwhelmed by secularism, religious beliefs will have no much room to be fully observed or exercised. People are more occupied with their worldly life.

With the advance of science and technology human beings do not seriously consider the necessity of religious belief for their life. They maintain that the reason is enough to be their guide for establishing a good and happy life. So, when the reason is enough, what need do people have after that? However, rationalism did not come only in modern time. It has also been developed since the early Islamic formative era. There were some rationalist figures maintaining the superiority of reason to divine revelation. Abu Bakr al-Rāzī, as has been quoted earlier, claimed that revelation is superfluous, or even hateful. When all human beings are endowed with reason, which will guide them to the pursuit of truth and good life, they will have no more need to revelation. Majid Fakhry, in his other work, A History of Islamic Philosophy, writes:

... al-Razi, in perfect consonance with his rationalistic premises, had rejected outright the concept of revelation and the role of the prophets as

6 "Communion and Stewardship: Human Persons Created in the Image of God", vatican.va, http://www.vatican.va/roman_curia/congregations/cfaith/ cti_documents/rc_con_cfaith_doc_20040723_communion-stewardship_en.html, accessed 28 Apr 2013. 


\section{Fauzan Saleh}

mediators between God and man. He reasoned that prophecy was either superfluous, since the God-given light of Reason was sufficient for the knowledge of the truth, or obnoxious, since it has been the cause of so much bloodshed and warfare between the one people (presumably, the Arabs) who believed itself to be favored with divine revelation and the other less fortunate peoples. ${ }^{7}$

Al-Rāzì was not the only leading figure in developing liberal thought during the heyday of Islamic rationalism, under the influence of Mu'tazilism. Another important figure worth of mention here is the free thinker Ibn al-Rawandi (d. ca. 910), who was also very much skeptical to the idea of prophecy. Like al-Rāzī, he also argued that human reason was sufficient to determine the knowledge of God and the distinction between good and evil. As he was affiliated to Mu'tazilites, such an idea was so familiar to him. Yet, he even went further by proclaiming that revelation was unnecessary, and miracles, upon which the claims of prophecy are alleged to rest, were altogether absurd. Moreover, he also rejected the miraculous wording of the Quran. As all Muslims believe, the Quranic wording was inimitable, which indicates its literary perfection. However, Ibn al-Rawandi said that such a belief was unsustainable. He argued that it is not beyond reason that an Arab man (i.e. Muhammad) should so excel all other Arab people in literary proficiency that his work would be unquestionably the best. ${ }^{8}$ In short, in addition to his rejection of the authority of Muhammad's prophecy, Ibn al-Rawandi did also not recognize the miracolousness of the Quran as the true words of God.

The rejection of the authority of the prophets has also been a longtime issue disputed among rationalist theologians. Muhammad 'Abduh (d. 1905), for instance, one of the most prominent Muslim reformers in the early twentieth century, wrote in his Theology of Unity, that among the reasons some people reject the authority of prophecy is that "if the mission of the prophets is an essential need of mankind for the perfecting of their social order and a way to well-being in both worlds, then why on earth is mankind still in such a troubled state?" They argue that even

${ }^{7}$ Majid Fakhry, A History of Islamic Philosophy (New York: Columbia University Press, 1987), p. 104.

8 Ibid., p. 96. Ibn al-Rawandi's argument most likely refers to some verses challenging the Arab literati, such as the Quran, 11: "Or they may say 'He forged it.' Say, 'Bring ye then ten Surabs forged, like unto it, and call (to your aid) whomsoever ye can other than Allah --if ye speak the truth."

9 Muhammad Abduh, The Theology of Unity, trans. by Ishaq Musa'ad and Kenneth Cragg (London: George Allen \& Unwin, 1966), p. 104. 
though the prophets are present in the world, people remain far from being happy. They fight against each other defending their respective belief, and thus there are more discords than concords among themselves. Accordingly, injustices fill men's thought and greed occupies their souls. It is not surprising to see partisans of each religion make their belief a ground of contention against those who hold different faith, leading to new enmities and resentments. In addition, advocates of one religion are broken away by schism into diversified schools of thought. Finally, "force takes over, instead of truth and religion becomes a shambles with the strong against the weak." 10

In defense of the necessity of prophecy, 'Abduh, first of all, realizes the veracity of the above allegation. It is indeed for this purpose that he discusses men's need of prophetic mission as one of the earnest topics conveyed in his Theology of Unity. For 'Abduh, the belief in the validity of prophethood is an important principle in Islamic doctrine. Otherwise, Muslims will lose the true guidance for their life or they will go astray. In reply to the above accusation, 'Abduh suggests that all the arguments presented by the adversaries of prophecy are due to the fact that after the time of the prophets, religion fell into the hands of those who failed to understand it correctly, or lapsed into extremism, or else they did not sincerely love it at all. Moreover, according to 'Abduh, their minds were in fact inadequate for its full implementation according to the examples provided by the prophet or the best of his followers. 'Abduh even further suggests that indeed the moral character is to be based on beliefs and traditions, and these can be established only on religion. 'Abduh argues that the religious factor is the most powerful of all, in respect both of public and of private ethics. It exercises an authority over men's souls superior to that of reason, despite man's uniquely rational powers. ${ }^{11}$

With regard to the inconsistency of reason and religion which is commonly used by the adversaries of revelation, 'Abduh said that the comparison between reason and religion involves some disparagement of the former in matters of faith. The advocates of rationalism suggest that faith is founded on pure submission and is quite discontinuous with rational investigation of the contents of religion, whether it be doctrines affirmed or directives enjoined. In response to that accusation, 'Abduh said that if the religion would not be a means whereby man could be guided, one must admit that mind alone does not suffice to attain the

${ }^{10}$ Ibid.

${ }^{11}$ Ibid., p. 106. 


\section{Fauzan Saleh}

condition in which the well-being of humankind resides. It needs a divine guide. Likewise, animals cannot solely rely on sight among their senses but must also use hearing. In this regard, religion is a general 'sense' by which mankind may discover the things that elude reason among the means of happiness. Mind is authoritative for the knowledge of this faculty and its exercise in its proper field. Mind submits to the doctrines and rules of conduct that religion reveals. ${ }^{12}$

\section{Prophethood in Islam}

As generally believed, prophethood is an essential foundation in Islamic faith. To say the truth, Islam cannot be established without the belief in prophethood. Even in other heavenly revealed religions, such as Judaism and Christianity, prophethood has become a fundamental tenet as well as a source of their doctrines. Nevertheless, prophethood in Islam has a special status and significance. It is believed that according to Islam, God has created man for a noble purpose: to worship Him and to lead a virtuous life based on His guidance. How would mankind know his role and the purpose of his existence without the clear and practical instructions conveyed by the messengers of Allah who guide him to do for his own well-being? Here comes the need for prophethood. It is really for this noble purpose that Allah has chosen from every nation at least one prophet to convey His message to mankind. ${ }^{13}$ In line with this idea, 'Abduh, in his work quoted above, suggests:

The messengers, then, are the signs God has given to guide men in the way of salvation. Those who have accepted the guidance have come to happiness. Those who have misunderstood or fallen away from their light have come to a bitter end. Religion is a guide. But human weakness impedes those who are called to takes its guidance to themselves. Yet that weakness does not disqualify the perfection of religion, nor yet man's urgent need for it. ${ }^{14}$

In general, prophethood is divine blessing and favor. Allah has chosen some particular figures to be His messengers as He wills. However, there are some particular features by which a prophet can be recognized, based on general characteristics of the various messengers being surveyed

${ }^{12}$ Ibid., p. 107.

13 "Prophethood in Islam", islamawareness.net, http:/ / www.islamawareness.net/ Prophets/prophethood.html, accessed 9 Sep 2013.

${ }^{14}$ Fakhry, A History, p. 106. 
throughout history: ${ }^{15}$

- He is the best in his community in terms of morality and intellectuality, since a prophet's life should become a role model for his followers. Moreover, his character must draw people's recognition and thus they would accept his message rather than drives them away by his flawed nature. After receiving divine message, he is infallible, in the sense that he would not commit any sin.

- He is supported by miracles to prove that he is truly a genuine messenger of God. Those miracles are granted by the power and permission of God and are usually in the field in which his people are recognized as enormously excellent.

- Every prophet states clearly that the message he has to deliver does not originate from his own mind, but definitely from God for the wellbeing of mankind. He also validates all the messages being revealed before him and what may be revealed after him. A prophet does this only to show that he is simply conveying the message being entrusted to him by the One True God of all people in all times.

The above exposition clearly explains how prophecy is very essential in religious belief, by virtue of which divine messages are made known to mankind so as they may follow the right path to achieve their salvation. Since prophecy is very essential in religious life, and thus it has a great influence on worldview held by the believers, it is not surprising to note that some Muslim philosophers also recognize the veracity of prophecy, although they put it in a different way from the one exposed by Muslim theologians. While the theologians suggest that prophecy, as mentioned above, is God's blessing and favor, and thus every message conveyed by the prophet truly came from God delivered by Archangel Gabriel, the philosophers maintain that prophecy is ascribed to an exceptional perfection of the imaginative faculty. ${ }^{16}$ This idea, being attributed to alFarabi, implies that prophecy does not necessarily signify God's blessing.

The idea of imaginative faculty could be an outcome of one's earnest intellectual training which could be achieved by anybody disregarding whether or not he is favored by God. Likewise, Ibn Sīnā, another leading Muslim philosopher, assigns prophecy to the holy Reason, described as the highest stage which human reason can attain. ${ }^{17}$ Again, by this idea, Ibn Sīnā does not seem to acknowledge the divine authority

15 "Prophethood in Islam".

${ }^{16}$ Fakhry, A History, p. 142.

${ }^{17}$ Ibid. 


\section{Fauzan Saleh}

attributed to the prophets. It is clear, therefore, that both al-Farabi and Ibn Sina tend to derogate the sacredness of the prophetic office held by the messengers of God. However, unlike al-Rāzī who boldly rejects the necessity of divine revelation and considered it as superfluous, both al-Farabi and Ibn Sīnā believe that prophecy is a valid instrument in establishing religious life. They even tried to support the veracity of prophecy by some rational arguments, based on philosophical reasoning. ${ }^{18}$ In Ibn Sīnā's point of view, unlike the one held by theologians, the prophet obtains his knowledge not through divine revelation conveyed to him by the Archangel Gabriel, but rather due to his exalted intellectual aptitude. The prophet was provided the highest degree of lucidity or susceptibility for contact with higher intellectual agencies, so that he has the ability to receive the enlightenment of the active intellect in all matters. As soon as he attains that level, the intelligible forms stored in the active intellect will appear to him right away, and thus he will apprehend them without effort. This is unlike ordinary people who may catch the notion of reality only through learning or by the assistance of a teacher. ${ }^{19}$ Again, this seems to signify that the prophet is not the one uniquely chosen by God to be His messenger, but merely because he has successfully developed his intellectual capacity. For Ibn Sīnā, therefore, the prophets are characteristically like philosophers.

In addition to al-Farabi and Ibn Sīnā, another Muslim philosopher having a deep concern with the validity of Muhammad's prophecy is alKindi (d. c. 866). He maintains that the truth of Muhammad's revelation can be demonstrated syllogistically in a manner which only the ignorant would dispute, or that the superiority of revealed truth over human wisdom is an instance of the privileged status of the prophets, who are God's spokesmen and the bearer of a "divine science" transcending human capability. ${ }^{20}$ By this idea, al-Kindi suggests that Muhammad's status as a prophet with divine revelation fortifying his message is genuinely valid to be trusted by mankind. It is not surprising, therefore, when we see al-Kindi upholding such an idea, because he had been so acquainted with the Mu'tazilite theological views before he became a philosopher. Within Mu'tazilism, prophethood has a very strong position as foundation of belief. Moreover, with his Mu'tazilite background, al-Kindi was very much closer to genuine Islamic doctrines in his thought than any other
${ }^{18}$ Ibid., p. 143.
19 Ibid., p. 144.
20 Ibid., p. 96. 
philosopher. His sincere defense of the fundamental tenets of Islam reflects his philosophical reasoning.

\section{Said Nursi on the Necessity of Prophethood}

In Said Nursi's point of view, prophethood is very essential for mankind. First of all, he established his idea on the natural fact to be the basis for his argument that God does not leave ant without leader, or bees without queen. By this simple fact, Nursi concludes that God would not leave mankind without prophet or code of law, by virtue of which they will have their guidance to go through their life peacefully. Nursi's argument, though sounds fairly simple, is indeed very interesting to be discussed more seriously, especially since he tries to put it in a modern context. His Risale-i Nur has provided a very extensive discussion on this issue, including the ones elaborated in his Words and Flashes. According to Nursi, prophethood in mankind is the summary and foundation of human perfection and goodness. Otherwise, mankind could not achieve his ultimate refinement of humanity. Through the messages of the prophet, God has revealed the true religion as the index or directory of prosperity and happiness. It is in the hands of the prophet that all goodness and shining beauty as well as human perfection lie. On the contrary, all evils, misguidance and loss will befall on those who oppose the prophet. ${ }^{21}$

It is interesting that in explaining the necessity of prophethood, Nursi also gives a fair consideration to those who might hesitate to accept the veracity of the prophetic messages. In his I'caz, verse 7, 31-32, for instance, Nursi mentions that supposed one would ask "the outlooks [mesalik] of the prophets are all different and their ways of worship are diverse. What is the reason for this?" This skeptical inquiry is of course very understandable, and it might come from anybody having a critical mind in reconsidering the historical facts that happened in the past. In response to this criticism, Nursi said:

The prophets are all followed in the principles of faith and fundamental rules, for these are constant and fixed; unlike secondary matters, the nature of which is to change in the course of time. Just as the four seasons and the stages in a person's life warrant different remedies and clothing -what is a cure at one time may cause illness at another- so the stages of the life of humanity necessitates differences in rules of secondary importance,

${ }^{21}$ Bediuzzaman Said Nursi, The Flashes Collection, trans. by Sukran Vahide (Ankara: Ihlas Nur Nesriyat, 2007), p. 185. 


\section{Fauzan Saleh}

which are healing for spirits and nourishment for hearts. ${ }^{22}$

It is clear from the above quotation that although every prophet has a particular way in undertaking the ritual formulas, these formulas are to be considered as secondary matters. Nonetheless, the prophets ordain the same and unchangeable fundamental rules with regard to the belief. While the fundamental rules and principles of faith are constant and fixed, the ritual formulas, as secondary matters, are alterable in the course of time. Nursi has lively explained it with a figurative description, just like the four seasons which require particular clothing for mankind to put on. Of course it is by no means true that every nation is allowed to formulate its own way in worshipping God. It is only the authority of the prophets to design the ritual formula, based on divine revelation. This is true, as approved by the ulama or Muslim clerics that all formula of worship must be based on divine ordinance, and it is none of the authority of anybody else to prescribe it. In matters of the way in worshipping God, mankind is ordained to follow the ways exemplified and practiced by the Prophet Muhammad himself. In other words, fabricating the formulas of rituals beyond the ones prescribed by the Prophet is forbidden.

Another important point suggested by Nursi as the way to prove the necessity of prophethood deals with the essential nature of life. Nursi maintains that since the universe was created for life, and life is a greatest manifestation of the Pre-Eternal Self-Subsistent One, which is also a perfect inscription of His most beautiful work of art, so too it is prophets and scriptures they bring that make known the words of God who speaks from beyond the world of unseen, beneath the veil of the universe. It is God who commands and prohibits trough the utterance of His will. But His words would not be known to mankind without the help of the chosen ones who become His messengers to convey divine revelation. In short, "just as the life in the universe testifies decisively to the necessary existence of the Pre-Eternal-Living One, it looks also to the pillars of belief the sending of prophets and revelation of scriptures, which are rays, manifestations, and communications of that Pre-Eternal Life." ${ }^{23}$

Nursi also suggests that God, the possessor of the universe, does everything with knowledge, disposes every affair with wisdom, and

${ }^{22}$ Bediuzzaman Said Nursi, Signs of Miraculousness: The Inimitability of the Quran's Conciseness, trans. by Sukran Vahide (Istanbul: Sozler Publication, 2007), p. 32.

${ }^{23}$ Nursi, The Flashes Collection, p. 468. 
treats everything all-knowingly. Accordingly, He will speak to those who posses consciousness and thought, and those who will understand His speech. Basically, God will address mankind to make them understand His will and command. In Nursi's point of view, since God will speak to mankind who posses consciousness and thought, it naturally indicates that mankind's nature and awareness are the most comprehensive of all conscious beings. However, it will be hard to believe that God will speak to anybody arbitrarily. As the most Wise Being, God will choose only the most appropriate individuals to speak to. Surely, He will speak to the most perfect of mankind and those most worthy of address. Like some other prophets before him, Muhammad really fulfills such a qualification. Moreover, he is the most worthy of address, because he is the highest in morality, and "who is obeyed by one fifth of humanity, to whose spiritual rule half of the globe has submitted, with radiance of whose light the future of mankind has been illuminated for thirteen centuries." 24

Thus, Muhammad (PBUH) has the authority to guide mankind to the highest extent of humanity. His authority as such has been reflected in the daily conducts of the believers around the globe. The believers, as the luminous segment of humanity, renew five times daily the oath of allegiance to Muhammad, "for whose happiness they pray, for whom they call down God's blessing and bear admiration and love in their hearts." According to Nursi, the reality of Muhammad's prophecy was the reason for which the world was created, and is its result and most perfect fruit. This is because Muhammad is the supreme master of mankind and its greatest prophet, as well as the glory of the world. Nursi even quotes a saying narrated by al-'Ajluni in his Kashf al-Khafa' that indicates a divine address to Muhammad, revealing "if not for you, if not for you, I would not have created the sphere." ${ }^{25}$ It is clearly comprehensible that with the above quotation Nursi wants to suggest that the creation of the universe was intended to fortify the veracity of Muhammad's prophecy. Nursi then explains some particular testimonies to lead our understanding that God the almighty has sent Muhammad as the last envoy to reveal His messages to the whole mankind. Among other important proofs referred to by Nursi shows that prophethood proceeds from eleven of his attributes and states. Muhammad's appearance in the world, despite his being illiterate, suddenly and without experience with a religion which has left in amazement the learned men and philosophers of fourteen centuries and

${ }^{24}$ Nursi, The Letters, $19^{\text {th }}$ Letter, $1^{\text {st }}$ Sign, (Ihlas Nur Nesriyat), p. 129.

25 As quoted from Isma'il ibn Muhammad al-'Ajluni, Kashf al-Khafa', II: 164. 


\section{Fauzan Saleh}

has won first place among the revealed religions is an attribute without equal. Also unequaled is the fact that Islam, which emerged from his words, actions and conduct, has at all times educated and trained the spirits, souls, and minds of three hundred and fifty million people, taking them to spiritual advancement. In addition, Muhammad also comes with the Shariah, the divine law revealed to rule humankind with its righteous decree, leading to material and spiritual progress. ${ }^{26}$

In addition to the Shariah as a divine law to lead the material and spiritual progresses, Muhammad also displayed the particular way to worship God, imitating no one. It means that the way to worship God and servitude to Him has been genuinely based on divine decree of God, no fabrication or imitation from any form of servitude held by other belief or tradition. Also, since Allah has appointed Muhammad as the greatest teacher, best master, and truest guide, “... we should ask this master the question we asked our Creator." Among other things it is a question about the reality of resurrection, which is the most strange and awesome matter beyond the reason. Such a question could be solved only through the instruction conveyed by the true prophet Muhammad, who claimed it throughout his life, confirmed by all the prophets and saints, and the tongue of the World of Unseen. ${ }^{27}$.

The belief in the day of resurrection or eschatology is one of the fundamental tenets in Islam. The earlier Surahs or chapters of the Quran revealed to Muhammad are replete with description of that day, such as "A day on which no soul hath power at all for any (other) soul. The absolute command on that day is Allah's." [82:19]. The verse signifies that everyone is responsible for his or her actions, because, no soul can assume the burden of another soul. More terrifyingly, every limb will

${ }^{26}$ The Shariah is the fundamental law of Islam, as well as its constitution. It encompasses legislation derived from the Quran and the Hadith or the sayings attributed to Muhammad, though not all verifiable; see Caesar E. Farah, Islam: Beliefs and Observances (New York: Barron's Educational Series, 2000), pp. 155-56; Wael B. Hallaq, A History of Islamic Legal Theories: An Introduction to Sunni Usul al-Figh (Cambridge: Cambridge University Press, 1997), p. 235. According to Hallaq, the Shariah is nothing but a way or method of conduct (minhäj) that expresses belief in God, and each nation or group conceives of a particular way that suits its needs, to express its own belief in the one and only God. This is why religion is but one, emanating from one God, but the Shariah governing societies commensurately differ in accordance with the differences existing among these societies.

${ }^{27}$ Bediuzzaman Said Nursi, The Rays, trans. by Sukran Vahide (Istanbul: Sozler Publication, 2006), pp. 240-1 
testify either for or against its owner. Still another verse describing the reality of resurrection, reads:

And when the trumpet shall sound one blast. And the earth with the mountains shall be lifted up and crushed with one crash. Then on that day will the Event befall. And heaven will split asunder, for that day it will be frail. And the angels will be on the sides thereof, and eight will uphold the Throne of their Lord that day above them. On the day ye will be exposed; not a secret of you will be hidden (69:13-18).

The resurrection is aimed, as Muslims believe, to judge the deeds of men for the purpose of rewarding the faithful and punishing the wicked and sinful. ${ }^{28}$ That means the faithful would be delighted for the rewards guaranteed to compensate their good deeds they undertook in their worldly life. On the contrary, however, the wicked should be alarmed and thus become aware of the torment to be encountered on that terrifying day, as a consequence of their disobedience to God's decree. In accordance with such an idea, Annemarie Schimmel, in her work Deciphering the Signs of God (1994), puts forward "if individual death suffices as a warning, then the Koranic revelations about the Day of Judgment are meant to strengthen this warning." "29 Schimmel argues that there are numerous descriptions of "the Day," "the Hour" and "the Knocking One" --some particular terms used in the Quran to describe the eschatological realities-- in the earliest revelations, which apparently indicate "this horrible event in new, ever more powerful words, sentences and whole süras." 30 In Islamic languages, as Schimmel notes further, the term qiyamah, "resurrection" often means something incredibly confused. In Turkish, for instance, when something is said to be kiyamat koptu, which plainly means that everything is upside down, it just to signify that something is in a terrible state. ${ }^{31}$

As strongly believed by every devout Muslim, the messengership of Muhammad is also fortified with many miracles coming from divine authority. Nursi mentions that the very personality of Muhammad

${ }^{28}$ Hallaq, A History of Islamic Legal Theories, p. 113.

${ }^{29}$ Annemarie Schimmel, Deciphering the Signs of God: a Phenomenological Approach to Islam (Albany: State University of New York Press, 1994), p. 234.

30 Ibid. Schimmel refers to the Quran, 81 (al-Takwīr, The Folding Up), which reads, among the others: "When the sun (with its spacious light) is folded up, when the stars fall, losing their luster, when the mountains vanish (like a mirage), ... when the Blazing Fire is kindled to fierce heat... then shall each soul know what it has forward."

${ }^{31}$ Ibid., p. 235. 


\section{Fauzan Saleh}

was a proof of himself "as brilliant as the sun, through the powerful testimony to his messengership and veracity of his thousands of miracles, attainments and perfections, and his elevated character and fine morality." As Nursi goes further, there have been more than three hundred sound narrations revealing his miraculous actions in accordance with the explicit verse of the Quran: "and the moon split" (54:1), and "When you threw, it was not you who threw; it was rather God that threw" (8:17). Nursi explains that as one of his astonishing miracles, the moon splitting happened just at the sign of a single finger of his hand. ${ }^{32}$ In the mean time, water flowed forth in five springs from the five fingers of the same hand, and entire thirsty army drank from these, by virtue of which the members of the army became witness to it. Again, another miracle happened when the Prophet Muhammad casted a handful of dust with the same hand at an army of the hostile tribe that attacked him. Inexorably, they fled away when the dust entered the eyes of all of them. There been hundreds of miraculous incidents related in sound narrations, and some about which there are unanimous reports as recorded in the books of Islamic history.

Another powerfully astonishing miracle of the Prophet Muhammad deals with the Quran, the very words of God. In Nursi's work, it comes in the Fourth Testimony to the veracity of Muhammad's prophecy, with its innumerable truths and proofs. Nursi says:

Yes, with all its veracious truths, the Quran ... has illumined fourteen centuries and governed through its unchanging laws one fifth of mankind; and from that time to this has challenged all those who have opposed it; and not even one of the suras of which anyone has dared to produce the like of; and as is proved in The Supreme Sign, whose six aspects are luminous

32 With regard to moon split, the Quran mentions only briefly. As a miraculous action performed by the Prophet Muhammad it took place at Mecca, about five years before the hijrah. There are some hadiths explaining about the event, as narrated by Anās b. Mālik, Abdullāh b. 'Abbās, and Abdullāh b. Mas'ūd, all of which can be retrieved in Sahīh al-Bukhäri. Anas b. Malik narrated: “The people of Mecca asked Allah's Apostle to show them a miracle. So he showed them the moon split into two halves between which they saw the Hiram mountain." However, there has been a long dispute among Muslim scholars with regard to the veracity of this miracle, as whether or it really happened. Al-Marāghī, for instance, tends to decline the authenticity of this event. He suggests that it did not happen at the time of the Prophet, but rather it will happen in the future, to be a sign of the coming of resurrection; see al-Marāghī, Tafsìr al-Maräghì, 18: 76-7; see also: "Splitting of the Moon", Wikipedia, the Free encyclopedia (2016), https:/ / en.wikipedia. org $/$ w/index.php?title=Splitting_of_the_moon\&oldid=716275789, accessed 18 Jun 2013; “Witnessing the Moon Splitting Miracle”, WikiIslam (23 Apr 2014), http:// wikiislam.net/wiki/Winessing _the_Moon_Splitting_Miracle, accessed 18 Jun 2013. 
and cannot be penetrated by doubts; and whose veracity is endorsed by six supreme 'stations'; which is based on six unshakable truths; and is eagerly and respectfully recited every moment by hundreds and millions of tongues, and is inscribed with its sacredness on the hearts of hafizes; and whose testimony proceeds all the testimony and belief of the World of Islam; and from whose source flow forth all the sciences of belief and of Islam; and just as it affirms all the previous revealed scriptures, so is it affirmed them; - with all its truth and all its proofs of its veracity, the Quran of Mighty Stature testifies to the truthfulness and messengership of Muhammad (peace and blessings be upon him). ${ }^{33}$

By the above lengthy quotation, Nursi maintains that the miraculousness of the Quran is so strong and trustworthy. As a divine miracle, the Quran has testified and strengthened the truthfulness of Muhammad's prophecy. It also verifies the previous revealed scriptures and affirmed the true messages they conveyed. On the other hand, as the true words of Allah, the Quran continues to be at the core of Islam. According to Farah, to a religion that has no ecclesiastical organization, mystical ritual, and a body of saints whose aid the troubled soul may invoke, the Quran remains the principal inspiration and refuge for the Muslim. More than representing the supreme embodiment of the sacred beliefs of Islam, the Quran constitutes the Muslim's main reference not only for matters spiritual but also for mundane requirements of day to day living. It is not surprising, therefore, to find that the Quran is more widely read than any other sacred text, and thus more portions of it are committed to memory than those of any other similar body of sacred writings. To the Muslims, the Quran has profound historical and literary meaning besides serving as their manual of prayer, code of religious and ethical well-being, their guide to social behavior and daily living, and a compendium of useful definitions and maxims of practical value. ${ }^{34}$

\section{E. Concluding Remarks}

W. Montgomery Watt, in his work Muhammad Prophet and Statesman (1974), ends his discussion with a critical inquiry: "Was Muhammad a prophet?" After a lengthy line of reasoning, Watt then answers the question himself: "He was a man in whom creative imagination worked at deep levels and produced ideas relevant to the central question of human existence, so that his religion has had a widespread appeal, not only in his

${ }^{33}$ Nursi, The Rays, p. 595.

${ }^{34}$ Farah, Islam: Beliefs, p. 77. 


\section{Fauzan Saleh}

own age but in succeeding centuries." ${ }^{35}$ It is not clear what he actually has in mind when he describes Muhammad as such. He did not give a direct and clear answer to his own simple question. Instead, he just assumes that Muhammad worked merely through his imagination. Watt's standpoint seems to represent the one commonly held by skeptical philosophers. Implicitly, Watt did not recognize the validity of Muhammad's prophetic office with the authority to convey divine messages to mankind, let alone to extend God's blessing to the whole human beings, mainly to those who believe in Him.

On the other hand, presumably more impartial than Watt, Farah in his work cited earlier, mentions that Muhammad in his lifetime faithfully carried out what he regarded the will of God. Millions of Muslims never doubted that he was genuinely commissioned by Allah to deliver His commandments to the whole mankind. However, Muhammad's prophethood has been an object of suspicion and controversy for a very long time. Farah refers, among other things, to a biography of Muhammad written by Prideaux who regarded the Prophet's life as "a mirror to unbelievers, atheists, deists, and libertines." On the contrary, as Farah goes further, in Vie de Mahomet written by the Count de Boulainvilliers, Muhammad was portrayed "as a wise and enlightened lawgiver, who sought to establish a reasonable religion in place of the dubious dogmas of Judaism and Christianity." Farah also refers to another idea held by Thomas Carlyle who stated the prevalent view of Muhammad as "an impostor, an incarnation of falsehood, and that his religion was a combination of charlatanism and stupidity." But he quickly added that "such a view is a reflection upon ourselves." Carlyle argued, as reported by Farah, that "for countless people Muhammad's words have been the guiding star of their lives. Can it be possible that so many creatures created by God, have lived and died for something which must be regarded as a tragic fraud?" Even until today, the name of the Prophet Muhammad is evoked by nearly a billion faithful only with the qualifying phrase, "peace be upon him." It is only proper, therefore, that peace be attributed to him for his precious legacy both as a leader and a prophet. ${ }^{36}$ Farah must be genuinely true. How could a sincere man like Muhammad for whom about a billion people in the world, borrowing Nursi's words, "call down God's blessing and bear admiration and love in their hearts" be regarded

35 Montgomery Watt, Muhammad: Prophet and Statesman (Oxford: Oxford University Press, 1974), p. 204.

${ }^{36}$ Ibid., pp. 75-6. 
as an impostor or incarnation of falsehood? Of course, we are sure, that would be definitely inconceivable.

Finally, as Nursi has discussed extensively in his voluminous work, Risale-i Nur, it is clear that humankind needs the presence of prophet to guide them from being astray, in spite of their claim of intellectual aptitude. The veracity of his messengership has been proved by the abundant evidences, either in the forms of miraculous actions or luminous spiritual blessings disseminated to the believers sincerely observing his principal guidance. Nursi suggests that prophethood in mankind is the summary and foundation of human goodness and perfections, so that they may achieve true happiness and prosperity. In his Flashes, Nursi mentions that "Since in this world a shining beauty, an extensive and exalted good, an evident truth, and superior perfection are apparent, self-evidently truth and reality lie in prophethood and in the hands of prophets." 37 This avowal signifies that the order of universe depends on the presence of prophets who have the authority to bring forth divine guidance to them. In his Words, Nursi emphasizes that since God does not leave the ant without leader, or bees without a queen, He surely would not leave mankind without prophets or code of laws. This is because Muhammad (PBUH) has the authority to guide mankind to the highest extent of humanity. His authority as such has been reflected in the daily conducts of the believers around the globe. The believers, Nursi puts forward, as the luminous segment of humanity, renew five times daily the oath of allegiance to the Prophet Muhammad. "Every day in the tashahbud with millions of tongues the World of Islam declares 'Peace be upon you, O Prophet and may God's mercy and blessings be upon you."

${ }^{37}$ Nursi, The Flashes Collection, p. 174. 


\section{BIBLIOGRAPHY}

Ali, Abdullah Yusuf, The Meaning of the Holy Qur'an, Beltsville: Amana Publications, 1997.

"Communion and Stewardship: Human Persons Created in the Image of God", vatican.va, http://www.vatican.va/roman_ curia/congregations/cfaith/cti_documents/rc_con_cfaith_ doc_20040723_communion-stewardship_en.html, accessed 28 Apr 2013.

Fakhry, Majid, A History of Islamic Philosophy, New York: Columbia University Press, 1987.

----, A Short Introduction to Islamic Philosophy, Theology and Mysticism, Oxford: Oneworld, 1997.

Farah, Caesar E., Islam: Beliefs and Observances, New York: Barron's Educational Series, 2000.

Hallaq, Wael B., A History of Islamic Legal Theories: An Introduction to Sunni Usul al-Figh, Cambridge: Cambridge University Press, 1997.

Abduh, Muhammad, The Theology of Unity, trans. by Ishaq Musa'ad and Kenneth Cragg, London: George Allen \& Unwin, 1966.

Al-Marāghī, Aḥmad Mustậāa , Tafsìr al-Marāghì, Beirut: Dār Iḥyā' al-Turath al-'Arabi, 1985.

Nursi, Badiuzzaman Said, The Words, trans. by Sukran Vahide, Istanbul: Sozler Publication, 2008.

----, The Rays, trans. by Sukran Vahide, Istanbul: Sozler Publication, 2006.

----, The Flashes Collection, trans. by Sukran Vahide, Ankara: Ihlas Nur Nesriyat, 2007.

----, Signs of Miraculousness: The Inimitability of the Qur'an's Conciseness, trans. by Sukran Vahide, Istanbul: Sozler Publication, 2007.

Schimmel, Annemarie, Deciphering the Signs of God: a Phenomenological Approach to Islam, Albany: State University of New York Press, 1994.

Watt, Montgomery, Muhammad: Prophet and Statesman, Oxford: Oxford University Press, 1974.

"Witnessing the Moon Splitting Miracle", WikiIslam, 23 Apr 2014, http:/ / wikiislam.net/wiki/Winessing _the_Moon_Splitting_Miracle, accessed 18 Jun 2013. 